\title{
SEXUALITY LAW REFORM AND THE LANGUAGE OF PROGRESS: WHAT LIES BEHIND STATEMENTS THAT EQUALITY FOR LESBIAN AND GAY PEOPLE IS INEVITABLE?
}

\section{KENT BLORE*}

Equality for lesbian and gay people is increasingly being treated as inevitable. This article questions this sense of inevitability by exploring three possible explanations: (1) a cynical explanation that the language of inevitability is being used as a rhetorical device, (2) a mechanical explanation that the impending equality is an effect of prior causes in time, and (3) a teleological explanation that history is progressing towards its purpose of achieving equality. The article concludes that invocations of inevitability do not stand up to theoretical scrutiny and explores what options are then open to equality activists.

\section{INTRODUCTION}

There is a prevalent sense in Western societies that equality for lesbian and gay people is inevitable. This article seeks to problematise this sense of inevitability by exploring three tentative and intersecting explanations: (1) a cynical explanation that the language of inevitability is merely being used as a rhetorical device, (2) a mechanical explanation that the impending equality is simply an effect of prior causes in time, and (3) a teleological explanation that history is unfolding according to its purpose of obtaining equality for all. Each explanation will be given a theoretical leg to stand on which will then be interrogated.

Though the author sympathises with the objectives of equality activists, the article concludes that invocations of inevitability do not stand up to theoretical

\footnotetext{
* BA, LLB (Hons) (UQ), GDipLegalPrac (Griffith). The author would like to thank James Muldoon, Leah Carr, Jonathan Crowe and the anonymous reviewer, all of whom provided encouragement and insightful comments on earlier drafts, as well as the librarians at the State Library of Victoria who were unfailingly helpful.
} 
scrutiny. None of the explanations provide a basis for believing that equality is inevitable. Rather than being preordained, equality requires a constant and conscious struggle by political actors. Faced with this reality, the article explores what options are open to equality activists. They may become despondent without the promise of a better future, they may become even more cynical — perhaps with some success - or they may generate a wholly new kind of activism that does not rely on assumptions of progress. Only by taking the latter path can we uncover what lies behind statements of inevitability and what is not being said by a progressivist lesbian and gay activism. For example, those who invoke inevitability tend to overlook countertrends away from equality and the possibility that formal equality is reversible.

At the time of writing, the Australian Capital Territory is defending the constitutional validity of its Marriage Equality (Same Sex) Act 2013 (ACT) in the High Court. ${ }^{1}$ The successful defence of this legislation or the introduction of equivalent legislation at the federal level would not render this article otiose. Not only would the achievement of marriage equality fail to mark the end of discriminatory laws - there are a host of other changes that need to be made before the law can be said to be sexuality-blind ${ }^{2}$ — but, crucially, the achievement of marriage equality would not mean that it had been inevitable all along, nor would it prove a related assumption that marriage equality would be enduring once enacted. Regardless of the state of the law at the time you read this article, you will only be able to see whether these assumptions are valid by delving into the logic behind the language of inevitability. Such analysis also contains important lessons for the future of lesbian and gay law reform activism and for any other push for equality which seeks to mobilise support through a narrative of inevitability.

First, this article will establish that there is in fact a sense of inevitability. To do so it will focus on the context with which the author is most familiar — the Australian social milieu. However, as the question of equality for lesbian and gay people - especially as it relates to marriage - has become an internationalised debate, some forays beyond Australia will be necessary.

\footnotetext{
${ }^{1}$ Transcript of Proceedings, Commonwealth v Australian Capital Territory [2013] HCATrans 299 (3 December 2013).

${ }^{2}$ To give three examples in but one Australian jurisdiction, see: Criminal Code 1899 (Qld) ss 208, 215 (unequal ages of consent for gay and heterosexual males); Adoption Act 2009 (Qld) ss 76, 89(7)(b)(v)(A) (a lesbian or gay man may only adopt a child who has particular needs and only if single); Kent Blore, 'The Homosexual Advance Defence and the Campaign to Abolish it in Queensland: The Activist's Dilemma and the Politician's Paradox' (2012) 12(2) QUT Law and Justice Journal 36 (the continued operation of the 'homosexual advance defence' in murder trials).
} 


\section{THE LANGUAGE OF INEVITABILITY}

If you listen very carefully to the same-sex marriage debate you will notice the language of inevitability being deployed by the advocates for equality. Once you tune your ears to it, you will notice that among all their other arguments are laced various iterations of the bare assertion that at some point - and sooner rather than later - same-sex marriage will simply happen. These statements are both outwardly directed, to tell their opponents that resistance is futile, and inwardly directed, as an affirmation that their position is correct because the tide of history is flowing in their direction.

Starting with the most obvious source of same-sex marriage discourse marriage equality lobby groups - a search for the word 'inevitable' on the Australian Marriage Equality website returns 54 hits, with only one instance not directly related to achieving equality. ${ }^{3}$ Some examples are the lobby group’s own propaganda. For example their 'case for marriage equality’ page reads:

Some day, same-sex couples in Australia will have the legal right to marry. That is inevitable. As with every major human rights advance, from the abolition of slavery to allowing women to vote, future generations will look back and wonder how anyone could have opposed such a basic human right. ${ }^{4}$

However, most (29 out of the 54) are external links to newspaper articles and opinion pieces in the popular press. Many of them relate to politicians announcing their belief that reform is inevitable - for example, VicePresident Joe Biden in the United States ('US') ${ }^{5}$ and Labor candidate Kieran McAnulty in New Zealand. ${ }^{6}$ In Australia, the list includes the Greens Senator, Sarah Hanson-Young, ${ }^{7}$ the Greens MP, Adam Bandt, ${ }^{8}$ and the Tasmanian

\footnotetext{
${ }^{3}$ Australian Marriage Equality, Search Results for 'Inevitable' (11 March 2013) <http://www. australianmarriageequality.com/wp/?s=inevitable>.

${ }^{4}$ Australian Marriage Equality, The Case for Marriage Equality: A Summary (14 November 2010) <http://www.australianmarriageequality.com/wp/get-informed/the-quick-case-formarriage-equality/>.

${ }^{5}$ Stephanie Coontz, 'Gay Marriage Isn't Revolutionary. It's Just the Next Step in Marriage's Evolution', The Washington Post (online), 7 January $2011<\mathrm{http}: / /$ www.washingtonpost.com/ wpdyn/content/article/2011/01/06/AR2011010604911.html>; 'Biden Says Gay Marriage is “Inevitable” Next Step', Herald Sun (online), 25 December $2010<\mathrm{http}$ ://www.heraldsun.com. au/ipad/biden-says-gay-marriage-is-inevitable-next-step/story-fn6s850w-1225976061149>.

${ }^{6}$ Kieran McAnulty, 'Where is Christian Compassion?', Stuff.co.nz (26 September 2012) $<$ http://www.stuff.co.nz/stuff-nation/7731559/Where-is-Christian-compassion>.

${ }^{7}$ Australian Marriage Equality, Senator Releases Ad Urging Julia \& Tony: “Don't Delay the Inevitable' (17 June 2012) <http://www.australianmarriageequality.com/wp/2012/06/17/ senator-releases-ad-urging-julia-tony-dont-delay-the-inevitable/>; 'Gay Marriage Vote
} 
Premier, Lara Giddings. ${ }^{9}$ The power of this language of inevitability is so pervasive that it ensnared even the former Prime Minister, Julia Gillard, who, although she opposed marriage equality 'for our culture [and] for our heritage', ${ }^{10}$ conceded that it is nonetheless inevitable. ${ }^{11}$ Many of the pages cite opinion polls which register the community's sense of inevitability about marriage equality. ${ }^{12}$ The remainder generally consist of bold assertions of inevitability with little supporting evidence, ${ }^{13}$ no doubt because lobby groups and journalists are forced to reduce their message to sound bites but also because such a search cannot easily capture more nuanced arguments that tend to employ modal verbs expressing inevitability such as 'will [happen]', 'shall [occur]', and 'must [be achieved]'. The results do show, however, that

Should Be on Conscience, Greens Senator Sarah Hanson-Young Says', The Australian (online), 6 July $2011<$ http://www.theaustralian.com.au/news/breaking-news/gay-marriagevote-should-be-on-conscience-greens-senator-sarah-hanson-young-says/story-fn3dxity1226089051549>.

${ }^{8}$ Australian Marriage Equality, Bandt: Same-Sex Marriage 'Inevitable' (6 September 2011) $<$ http://www.australianmarriageequality.com/wp/2011/09/06/bandt-same-sex-marriageinevitable/>.

${ }^{9}$ Australian Marriage Equality, Tasmanian Premier Says Marriage Equality 'Inevitable' (6 October 2011) <http://www.australianmarriageequality.com/wp/2011/10/06/tasmanianpremier-says-marriage-equality-inevitable/>.

10 Sarah Le Marquand, 'Julia Lives Her Life with Gay Abandon', The Daily Telegraph (online), 28 June $2011<$ http://www.dailytelegraph.com.au/news/opinion/julia-lives-her-lifewith-gay-abandon/story-e6frezz0-1226082987170>.

${ }^{11}$ Rodney Croome, 'Thirteen Marriage Equality Moments in 2012', Gay News Network (21 December 2012) <http://gaynewsnetwork.com.au/viewpoint/viewpoint/10086-thirteenmarriage-equality-moments-in-2012.html>; Australian Marriage Equality, 'PERFECT HOSTESS': PM Opens Up on Gay Marriage (23 February 2012) <http://www.australian marriageequality.com/wp/perfect-hostess-pm-opens-up-on-gay-marriage/>; Jessica Wright, 'Gay Marriage “Inevitable”, Gillard Tells Guests', Brisbane Times (online), 22 February $2012<$ http://www.brisbanetimes.com.au/opinion/political-news/gay-marriage-inevitablegillard-tells-guests-20120221-1tlun.html>.

12 See, eg, Alex Greenwich, 'Gay Marriage Will Go Nuclear for ALP', Daily Telegraph (online), 30 November $2011<$ http://www.dailytelegraph.com.au/news/opinion/gay-marriagewill-go-nuclear-for-alp/story-e6frezz0-1226209549140>; Brian Greig, 'Greig: Christian Lobby Plays the Victim Card', Crikey (online), 16 August $2011<$ http://www.crikey. com.au/2011/08/16/greig-christian-lobby-plays-the-victim-card/>; Australian Marriage Equality, 3 in 4 Australians Believe Same-Sex Marriage 'Inevitable' (8 June 2011) $<$ http://www.australianmarriageequality.com/wp/2011/06/08/3-in-4-australians-believe-samesex-marriage-inevitable-mum-asks-gillard-\%e2\%80\%98not-to-delay\%e2\%80\%99-in-new-tvcampaign/>.

${ }^{13}$ See, eg, ABC, 'Marriage Equality is Inevitable - Just Look at Its Critics', The Drum, 17 May 2012 (Tim Dunlop) <http://www.abc.net.au/unleashed/4015156.html>; Gavin Marshall, 'Labor Must Do What Is Just And Back Same-Sex Marriage', The Sydney Morning Herald (online), 16 November $2011<$ http://www.smh.com.au/opinion/politics/labor-must-do-whatis-just-and-back-samesex-marriage-20111115-1nh37.html>; ABC, 'The Heart-Shaped Island', The Drum, 23 September 2011 (Rodney Croome) <http://www.abc.net.au/unleashed/ 2911966.html>. 
even unsubtle arguments about inevitability are infiltrating the socio-political landscape in Australia.

Another indication of the pervasiveness of this idea - this time from popular culture — is the 2012 hip-hop song 'Same Love' by Macklemore and Ryan Lewis from the US. ${ }^{14}$ As a measure of its popularity in Australia, it was voted $15^{\text {th }}$ in Triple J's Hottest 100 for $2012^{15}$ and then reached platinum sales figures and dominated the ARIA Charts at number one for four weeks in a row in early $2013 .{ }^{16}$ Although the lyrics reveal that it was written against the backdrop of the American debate about same-sex marriage — 'Till the day my uncles can be united by law' - it also tackles a number of other issues, including stereotypes about homosexuality, suicide ideation among lesbian and gay teens, and the derogatory use of 'gay' in the hip-hop genre and in online social media. If you analyse the choice of language more closely, two assumptions become apparent: first, that sexuality is immutable - the chorus echoes the message of Lady Gaga's 2011 song 'Born This Way' ${ }^{17}$ with the lyrics, 'I can’t change/ Even if I tried/ Even if I wanted to’ — and second, that equality for lesbian and gay people is inevitable. Macklemore, the singer and author of the lyrics, ${ }^{18}$ frequently employs the preposition 'until' to imply an endpoint to discrimination, for example, 'No freedom till we're equal'. Elsewhere in the song he reveals the philosophical basis for this kind of language - the idea that history is bettering itself as it moves forward: 'Progress, march on'.

On a level of slightly more nuanced debate, a recent book entitled Speak Now conveniently compiles the perspectives of the most prominent commentators on same-sex marriage in Australia. It is replete with examples of the language of inevitability. For example, Peter Tatchell, who co-ordinates the Equal Love campaign in the United Kingdom ('UK'), asserts, '[s]ame-sex marriage is an idea whose time has come. It is the growing trend all over the world'. ${ }^{19}$ This

\footnotetext{
${ }^{14}$ Macklemore and Ryan Lewis featuring Mary Lambert, 'Same Love', The Heist, Macklemore LLC, 2012.

${ }^{15}$ ABC, 'Hottest 100:15', Triple J, 26 January 2013 <http://www.abc.net.au/triplej/hottest100/ 12/countdown/15.htm>.

${ }^{16}$ Gavin Ryan, 'Macklemore and Ryan Lewis Same Love Spends $4^{\text {th }}$ Week at No 1', Noise 11, 10 February 2013 <http://www.noise11.com/news/macklemore-and-ryan-lewis-same-lovespends-4th-week-at-no-1-20130210>.

${ }^{17}$ Lady Gaga, 'Born This Way’, Born This Way, Streamline, Interscope and Kon Live, 2011.

${ }^{18}$ Jesse Mattheson, 'Macklemore: Why I wrote Same Love', Same Same (online), 23 January 2013 <http://www.samesame.com.au/features/9365/Macklemore-Why-I-wrote-Same-Love. htm>.

${ }^{19}$ Peter Tatchell, 'Dear Julia, the Public Supports Gay Marriage. Why Won't You?' in Victor Marsh (ed), Speak Now: Australian Perspectives on Same-Sex Marriage (Clouds of Magellan, 2011) 222, 222.
} 
identification of a trend towards equality for homosexuals was given a Hegelian overtone by Kerryn Phelps in a speech she delivered at the Sydney Mardi Gras in 2011 which was later republished in Speak Now. She said, ' $\mathrm{t}$ ] he Zeitgeist ... is with us and we have the momentum to succeed' ${ }^{20}$ and '[w]e stand on the threshold of change'. ${ }^{21}$ Alyena Mohummadally and Catherine Roberts implicitly locate this trajectory in the history of sexuality law reform to date when they say:

The passage of the Relationships Act 2008 (Vic) and the subsequent introduction of the 'relationships register' in Victoria represented a significant — although not ideal — step forward in the slow race to equality. ${ }^{22}$

Similarly, Monash University academics Adiva Sifris and Paula Gerber identify 'a general trend towards tearing down discriminatory barriers between same-sex and opposite-sex couples in all areas of the law' ${ }^{23}$ Of course, the identification of trends may not necessarily equate to fatalism. Trends may be acknowledged without deducing from them that any particular result is inevitable. However, in these instances the authors not only identify patterns but also an endpoint - lesbian and gay equality — which they then appear to treat as a logical and certain conclusion. ${ }^{24}$

Other contributors to Speak Now look beyond a trend towards lesbian and gay equality, and place the debate within the context of a broader movement through history towards equality for all. Rodney Croome, the campaign coordinator of Australian Marriage Equality, links ‘today's freedom to marry movement' to 'the movements before it'. ${ }^{25}$ Zenith Virago, a marriage celebrant, writes:

${ }^{20}$ Kerryn Phelps, 'Marriage Equality: No More Lame Excuses' in Victor Marsh (ed), Speak Now: Australian Perspectives on Same-Sex Marriage (Clouds of Magellan, 2011) 184, 189.

${ }^{21}$ Ibid 190.

${ }^{22}$ Alyena Mohummadally and Catherine Roberts, 'When Worlds, Happily, Collide' in Victor Marsh (ed), Speak Now: Australian Perspectives on Same-Sex Marriage (Clouds of Magellan, 2011) 135, 137.

${ }^{23}$ Adiva Sifris and Paula Gerber, 'It Makes No Sense: Adoption by Same-Sex Couples in Australia' in Victor Marsh (ed), Speak Now: Australian Perspectives on Same-Sex Marriage (Clouds of Magellan, 2011) 211, 217.

${ }^{24}$ See, eg, ibid, where exclusion of same-sex couples from adoption is described as 'inconsistent and illogical'. If the inconsistency relates to a difference in approach between jurisdictions it does not follow that one approach is illogical and the other logical. Accordingly, the conclusion that it is not logical seems to be because it is not consistent with the trend towards an endpoint which is deemed logical.

${ }^{25}$ Rodney Croome, 'A History of Freedom to Marry in Australia' in Victor Marsh (ed), Speak Now: Australian Perspectives on Same-Sex Marriage (Clouds of Magellan, 2011) 44, 46. 
In the long and constant struggle for a more humane world which acknowledges equal rights for every human being, we are reminded of some other past and current causes, freedom of slaves in the US and elsewhere, equality between all races regardless of colour [sic] of their skin or religious views, women's suffrage and the ongoing battle for respect and equality ... It seems to many people that the campaign for homosexual rights, recognition and equality is the last fight in a long history of prejudice and domination. ${ }^{26}$

Even focusing on the trend towards equality within the institution of marriage, Paul Martin points out that we now laugh at 'those in the past who opposed mixed race marriages ${ }^{27}$ and the Reverend Dorothy McRae-McMahon notes that the power balance between women and men within marriages has 'shifted towards equality'. ${ }^{28}$

Many of the contributors harbour reservations, chiefly centred around who will be excluded from the new equality, such as polyamorous queers who do not fit the monogamous model of heterosexual marriage. ${ }^{29}$ But even these reluctant converts are resigned to equality. Dennis Altman, who refuses to 'buy into the most conventional morality' through marriage still states unblinkingly that 'Australia will probably legalise same-sex marriage within the next decade'. ${ }^{30}$ Employing more fatalistic language, Wayne Morgan — an academic from the Australian National University College of Law, with similar views on marriage - writes: 'Like many others, I see the recognition of same-sex marriage in Australia as inevitable. It is not a question of whether it will happen, the only question is when'. ${ }^{31}$ Crusader Hillis, a self-avowed marriage agnostic, looks beyond lesbian and gay equality to other equalities: 'I expect first to see equality under the law, and then for the law to take into account the many and varied complexities that modern relationships bring

${ }^{26}$ Zenith Virago, 'Conducting Commitment Ceremonies' in Victor Marsh (ed), Speak Now: Australian Perspectives on Same-Sex Marriage (Clouds of Magellan, 2011) 230, 232.

27 Paul Martin, 'Gathering the Pieces' in Victor Marsh (ed), Speak Now: Australian Perspectives on Same-Sex Marriage (Clouds of Magellan, 2011) 120, 120.

${ }^{28}$ Rev Dorothy McRae-McMahon, 'Are You and Ali Married, Grandma?' in Victor Marsh (ed), Speak Now: Australian Perspectives on Same-Sex Marriage (Clouds of Magellan, 2011) 116, 116.

${ }^{29}$ See, eg, Maria Pallotta-Chiarolli, “"Messing Up the Couples' Cabinet”: On the "Queerly Mixed" Borders of the "Residual" and the "Emergent" in the Marriage Debates' in Victor Marsh (ed), Speak Now: Australian Perspectives on Same-Sex Marriage (Clouds of Magellan, 2011) 166; see also her fatalism at 180.

30 Dennis Altman, 'Why Gay Marriage?' in Victor Marsh (ed), Speak Now: Australian Perspectives on Same-Sex Marriage (Clouds of Magellan, 2011) 1, 1.

${ }^{31}$ Wayne Morgan, 'A Brief History of Relationship Law Reform in Australia' in Victor Marsh (ed), Speak Now: Australian Perspectives on Same-Sex Marriage (Clouds of Magellan, 2011) $143,149$. 
with them. ${ }^{32}$ Similarly, Damien Riggs from Flinders University asks what will happen after the inevitable:

What will happen once this subsection [of white, middle class, monogamous homosexuality] achieves equality with their matched sample within the heterosexual community? Will we sit back and rest easy, or will we make sure that everyone else who experiences disenfranchisement is given their fair go, too? ${ }^{33}$

Michael Kirby sees the potential for equality beyond only a queer agenda by suggesting that 'then ... we can turn our attention to other irrational hates and fears ... on the way to full civil equality in a truly civilised society'. ${ }^{34}$

This fatalistic language is perhaps most marked in the popular press and in regard to same-sex marriage, but it extends to academic journals and in regard to other topics of sexuality law reform. One example in Australia is the recent special edition of the journal Law in Context, devoted to the topic of the regulation of same-sex relationships. In the foreword, Michael Kirby provides a brief overview of human history that purports to reveal a 'process' toward recognising fundamental human rights, ${ }^{35}$ and then a similarly truncated version of gay history is given to show that 'history is moving, and moving quickly'. ${ }^{36}$ At the outset of the introductory article, Paula Gerber and Adiva Sifris embrace a five-stage process to the evolution of lesbian and gay law reform which begins with criminalisation and ends in formal equality. ${ }^{37}$ They recount their own version of lesbian and gay history and, while noting setbacks to the march of progress and that not all parts of the globe are marching in unison, ${ }^{38}$ they conclude that 'societies around the world are rapidly and irrevocably changing the way they look at same-sex relationships and families' such that 'there is reason to be optimistic'. ${ }^{9}$ Most of the remainder of the edition is similarly assured of an increasingly positive future for lesbian and gay people. For example, Adiva Sifris traces law reform trends

32 Crusader Hillis, 'Thoughts of a Marriage Agnostic' in Victor Marsh (ed), Speak Now: Australian Perspectives on Same-Sex Marriage (Clouds of Magellan, 2011) 97, 98.

33 Damien W Riggs, 'The Racial Politics of Marriage Claims: Rights and Relationships in Colonial Contexts' in Victor Marsh (ed), Speak Now: Australian Perspectives on Same-Sex Marriage (Clouds of Magellan, 2011) 191, 192.

34 Michael Kirby, 'Foreword' in Victor Marsh (ed), Speak Now: Australian Perspectives on Same-Sex Marriage (Clouds of Magellan, 2011) xix, xxv.

${ }^{35}$ Michael Kirby, 'Foreword’ (2011) 28(1) Law in Context vii, viii.

${ }^{36}$ Ibid $\mathrm{x}$.

37 Paula Gerber and Adiva Sifris, 'The Wind of Change is Blowing' (2011) 28(1) Law in Context 1,1 .

${ }^{38}$ Ibid 2.

${ }^{39}$ Ibid 6. 
in Australia to conclude that the legal recognition of lesbian parenting is imminent. ${ }^{40}$ To do this, she uses a sophisticated theory of causation to which we will return later in the article. Charlotte Frew's article constructs a history of the evolution of the institution of marriage since Australia was colonised. She detects in that history a number of patterns, including the liberalisation of popular opinion, ${ }^{41}$ increasing support for marriage reform from within religious communities, ${ }^{42}$ and the success of previous libertarian causes. ${ }^{43}$ Her reading of these trajectories allows her to conclude, 'If marriage continues to evolve according to this pattern, the legalisation of same-sex marriage is almost inevitable. ${ }^{44}$ Jamie Gardner traces international rather than domestic patterns to likewise conclude that 'the quest for same-sex marriage laws in Australia is no longer a dream but very much a reality" ${ }^{45}$ because the same impetuses that led to marriage equality elsewhere are also present here.

This style of language also harks back at least to the nascence of the gay liberation movement. In the wake of the Stonewall Riots in 1969, Merle Miller outed himself in the New York Times in one of the first opinion pieces in defence of homosexuality. In it he wrote, 'Laws discriminating against homosexuals will almost surely be changed. If not this year, in 1972; if not in 1972, in 1976; if not in 1976 .... ${ }^{46}$ Soon afterwards, in one of the seminal texts of gay liberation, Homosexual: Oppression and Liberation, Dennis Altman defined 'gay liberation' in terms of a trajectory towards an ultimate goal for civilisation: gay liberation 'represents a process whereby homosexuals seek to come to terms with themselves and through selfaffirmation start out on the path toward human liberation' ${ }^{47}$ Although he saw liberation as requiring a radical restructuring of society rather than the integration of homosexuals within existing norms, he was still fatalistic about the prospects of equality. He predicted — using the certain 'when' rather than the conditional 'if' — that:

${ }^{40}$ Adiva Sifris, 'Lesbian Parenting in Australia: Demosprudence and Legal Change' (2011) 28(1) Law in Context 8.

${ }^{41}$ Charlotte Frew, 'The Social Construction of Marriage in Australia: Implications for SameSex Unions' (2011) 28(1) Law in Context 78, 80.

${ }^{42}$ Ibid 82.

${ }^{43}$ Ibid 83.

${ }^{44}$ Ibid 78.

45 Jamie Gardiner, 'Same-Sex Marriage: A Worldwide Trend?' (2011) 28(1) Law in Context 92, 103.

${ }^{46}$ Merle Miller, On Being Different: What It Means to Be a Homosexual (Penguin Books, first published 1971, 2012 ed) 23. See also his afterword at 39: 'I am much more optimistic than when I wrote the piece, much; the laws, as I said, will be changed, sooner than I thought. Efforts are under way in every state, and they will, I think, succeed.'

47 Dennis Altman, Homosexual: Oppression and Liberation (University of Queensland Press, first published 1971, 2012 ed) 237. 
[g]ay liberation will have achieved its full potential when it is no longer needed, when we see each other neither as men and women, gay and straight, but purely as people with varied possibilities. ${ }^{48}$

Of course not all commentators are so optimistic, even leaving aside for a moment those who confidently believe that lesbian and gay rights are doomed to fail by religious design. ${ }^{49}$ There is, for example, a significant body of literature in the US which cautions against rights-based claims for lesbian and gay people because law reform can have unintended consequences, including regressive ones. ${ }^{50}$ This acknowledgement of regression runs counter to the narrative of progress that undergirds the language of inevitability. It may also be that a chronological review of language employed in lesbian and gay literature would reveal a dip in fatalism through the queer theory dominance of the 1990s and 2000s, given its disdain for the idea of progress, influenced as it is by postmodernism's 'incredulity towards metanarratives'. ${ }^{51}$ However, such a detailed and wide-ranging literature review is beyond the scope of this article. Moreover, the observation that much of the current debate around lesbian and gay equality is employing the language of inevitability suffices to spark the present discussion.

\section{EXPLANATIONS FOR THE SENSE OF INEVITABILITY}

How then can this sense of inevitability be explained? The present writer has identified three mutually reinforcing explanations, all of which appear to be motivating statements to the effect that equality will be achieved for lesbian

\footnotetext{
${ }^{48}$ Ibid 162. See also at 246.

${ }^{49}$ See, eg, Simon Mann, 'The Case against Legalising Same-Sex Marriage', The Age (online), 15 July $2012<$ http://www.theage.com.au/opinion/political-news/the-case-against-legalisingsamesex-marriage-20120714-2236g.html> (re opinion of conservative campaigner Jim Wallace). Cf, eg, John Milbank, 'Best of 2012: Gay Marriage and the Future of Human Sexuality', $A B C$ Religion and Ethics (4 January 2013) <http://www.abc.net.au/ religion/articles/2013/01/04/3664220.htm>: 'the Church needs already to face the fact that it is quite likely to lose this debate, even if it should still try to win it'.

${ }^{50}$ See, eg, Gerald Rosenberg, The Hollow Hope: Can Courts Bring About Social Change? (University of Chicago Press, 1991) 339-429; Didi Herman, Rights of Passage: Struggles for Lesbian and Gay Legal Equality (University of Toronto Press, 1994) 145; Nicola Barker, 'Ambiguous Symbolisms: Recognising Customary Marriage and Same-Sex Marriage in South Africa' (2011) 7(4) International Journal of Law in Context 447, 447, 453-5. For the feminist origins of this body of literature, see, eg, Carol Smart, Feminism and the Power of Law (Routledge, 1989) 49; Renee Romkens, 'Law as a Trojan Horse: Unintended Consequences of Rights-Based Interventions to Support Battered Women' (2001) 13(2) Yale Journal of Law and Feminism 265.

51 Jean-Francis Lyotard, The Postmodern Condition: A Report on Knowledge (Geoff Bennington and Brian Massumi trans, University of Minnesota Press, 1984) xxiv [trans of: La condition postmoderne: Rapport sur le savoir (first published 1979)].
} 
and gay people: a cynical explanation, a mechanical explanation, and a teleological explanation. In teasing out these three explanations, academics and activists are cited who epitomise each, though of course, in practice, few are likely to neatly adhere to this tripartite taxonomy. In a social and political struggle over rights, statements of inevitability are likely to have more than one explanation and the explanations ascribed to particular authors may be different from the one they intended or would intend if they turned their minds to this question. However, some reductionism is necessary for the sake of clarity. The article is seeking to adduce explanations for the sense of inevitability and not explanations for inevitability itself; hence, they are not held out as justified explanations.

\section{A Cynical Explanation: Rhetorical Device}

The first and most straightforward explanation is that law reform advocates are simply employing a rhetorical device. They are incanting a slogan over and over until it generates its own resonance. Like an affirmation, saying it aloud makes it more likely to come true. ${ }^{52}$ It is cynical in the sense that the veracity of the statement as to whether equality is in fact inexorable is irrelevant to the speaker.

Not all statements about inevitability fall into this category, only those instances that may be characterised as enthymemes - in either of the senses used by Aristotle, as reasoning from a premise that is only probably true ${ }^{53}$ or as a syllogism with an unstated premise. ${ }^{54}$ So for example, when Rodney Croome, the national convenor of Australian Marriage Equality, says, '[T]he Coalition ... cannot afford to maintain its blanket opposition to this inevitable and popular reform, ${ }^{55}$ or Dr Kerryn Phelps says, 'It's still inevitable it's just a

\footnotetext{
${ }^{52}$ Karl Popper refers to this 'influence of the prediction upon the predicted event' in the social sciences as the 'Oedipus effect', alluding to the Ancient Greek myth in which the oracle's prediction played a crucial role in Oedipus fulfilling it by murdering his father and marrying his mother: Karl R Popper, The Poverty of Historicism (Harper Torchbooks, $3^{\text {rd }}$ ed, 1961) 13.

${ }^{53}$ Aristotle, 'Rhetoric' in Jonathan Barnes (ed), The Complete Works of Aristotle: The Revised Oxford Translation (W Rhys Roberts trans, Princeton University Press, 1984) vol 2, 2152, 2157 (1357a 30). See generally at 2152-237 (Books I and II).

${ }^{54}$ Ibid 2157 (1357a 16); H W B Joseph, An Introduction to Logic (Oxford University Press, $2^{\text {nd }}$ ed, 1916) 350-2.

${ }^{55}$ Australian Marriage Equality, Young Libs Back Gay Marriage Free Vote (2 February 2013) $<$ http://www.australianmarriageequality.com/wp/2013/02/02/young-liberals-conferencesupports-marriage-equality-conscience-vote-advocates-say-pressure-mounting-for-abbott-toallow-mps-to-vote-according-to-their-beliefs/> .
} 
matter of time [sic], ${ }^{56}$ both are proceeding on the basis of an unstated premise. In Croome's case, his coupling of inevitability with popularity suggests that his hidden logic may run along these lines:

Same-sex marriage has overwhelming support in the electorate.

Reforms with the overwhelming support of the electorate are very likely to succeed.

Therefore the push for same-sex marriage is very likely to succeed.

There is then only a very little hyperbole needed to jump from 'very likely' to 'inevitable'. Phelps's reference to time may be a hint that the proposition underlying her argument of inevitability is that history is progressive.

The point, though, is that we cannot be certain what the bases of statements like these are. As Aristotle pointed out, they are aimed at persuasion, not at demonstrating their validity. ${ }^{57}$ For Plato, this preoccupation with persuasion means that rhetoricians lose sight of what it is they are trying to persuade others of. ${ }^{58}$ Whether their position is logically defensible becomes unimportant. It suffices that their arguments are accepted as 'true enough' 59 in the same way that the Sophists treated knowledge as contingent and therefore strategic. $^{60}$

While Plato's criticism of sloppy logic may be levelled against the lesbian and gay lobby groups and sympathetic public figures working in sound bites,

56 Peter Jean, 'Phelps Hits Same-Sex Stand', Canberra Times (online), 28 January 2013 <http://www.canberratimes.com.au/act-news/phelps-hits-samesex-stand-20130127-2dfdb. html>.

${ }^{57}$ Aristotle, above n 53, 2153-4 (1355a 4).

58 See, eg, Plato, 'Gorgias' in The Dialogues of Plato (B Jowett trans, Clarendon Press, $4^{\text {th }}$ ed, 1953) vol 2, 533, 550-1 (462b-462c), 553 (464c-465a); Plato, 'Phaedrus' in The Dialogues of Plato (B Jowett trans, Clarendon Press, $4^{\text {th }}$ ed, 1953) vol 3, 133, 167-8 (260a-260d), 177-8 (269b-269c).

59 Aristotle, above n 53, 2154 (1355a 14): 'For the true and the approximately true are apprehended by the same faculty'. Note though, that this was not a critical consideration for Aristotle who still considered that rhetoric was useful and unlikely to override the natural tendency of truth to prevail: 2154 (1355a 22).

${ }^{60}$ Ibid 2235 (1402a 24) (regarding the Sophist Protagoras's claim that he could 'mak[e] the worse argument seem the better'); Aristotle, 'Metaphysics' in Jonathan Barnes (ed), The Complete Works of Aristotle: The Revised Oxford Translation (W D Ross trans, Princeton University Press, 1984) vol 2, 1552, 1653 (1047a 4), 1664 (1053a 35), 1678 (1062b 12); Jonathan Lavery, 'Protagoras' in Patricia O'Grady (ed), The Sophists: An Introduction (Duckworth, 2008) 30; Daniel Silvermintz, 'The Double Arguments' in Patricia O’Grady (ed), The Sophists: An Introduction (Duckworth, 2008) 147. 
perhaps there is something more fundamental happening. Whether or not they consciously realise it, at least some fatalists are treating truth as something malleable rather than as something fixed and discoverable by reason. These fatalists are not overly concerned about the truth of their statements because they appreciate that what is accepted as truth is essentially a fiction; it is created. In the words of Michel Foucault, 'the discovery of truth is in reality a certain modality of the production of truth'. ${ }^{61}$ What Foucault means by this is that types of knowledge - and therefore what is accepted as true ${ }^{62}$ - are strategically shaped and organised by exercises of power. ${ }^{63}$ The relationship between knowledge and power, however, is a two-way street; knowledge also reinforces the machinations of power. In fact, knowledge and power operate almost interchangeably. ${ }^{64}$ They are so mutually reinforcing that it can be difficult to see which is the product of the other. Statements about the inevitability of equality then are a type of discourse, which is a way of trying to constitute knowledge. ${ }^{65}$ Even though equality activists represent an extremely small and underfunded segment of society, it is clear from the way that even their opponents are forced to concede inevitability that they are dominating the discourse on inevitability. The fact that they have a virtual monopoly over this discourse reveals something about the knowledge-power (pouvoir/savoir) dynamic in the background. By deploying this discourse on inevitability they are heading down the path of formulating knowledge, and if they are able to do this it must be because they have usurped a great deal of their opponents' power. ${ }^{66}$ This shift in power will only speed up because the knowledge formed in this way will in turn reinforce the authority of equality

61 Michel Foucault, Le pouvoir psychiatrique, Cours au Collège de France 1973-1974 (Gallimard Seuil, 2003) 238, quoted and translated in Clare O’Farrell, Michel Foucault (Sage Publications, 2005) 93.

${ }^{62}$ Foucault is concerned only with contingent truths; the existence or non-existence of universal truths underneath these contingencies is largely irrelevant to him: Michel Foucault, 'The Subject and Power' in James D Faubion (ed), Power: Essential Works of Michel Foucault, 1954-1984 (Robert Hurley et al trans, The New Press, 2000) 326, 330; Michel Foucault, 'The Concern for Truth' in Sylvère Lotringer (ed), Foucault Live Interviews, 1961-1984 (Lysa Hochroth and John Johnston trans, Semiotext(e), $2^{\text {nd }}$ ed, 1996) 455, 456. See similarly the views of Friedrich Nietzsche: Gianni Vattimo, Nietzsche: An Introduction (Stanford University Press, 2001) 135-6.

${ }^{63}$ O’Farrell, above n 61, 87.

64 See Foucault's references to the composite term 'knowledge-power' in Michel Foucault, Discipline and Punish: The Birth of the Prison (Alan Sheridan trans, Vintage Books, 1995) 27-8 [trans of: Surveiller et punir (first published 1975)]; Michel Foucault, The Will to Knowledge: The History of Sexuality Volume 1 (Robert Hurley trans, Penguin Books, 1998) 143 [trans of: La volonté de savoir (first published 1976)].

${ }^{65}$ Chris Weedon, Feminist Practice and Poststructuralist Theory (Blackwell Publishing, $2^{\text {nd }}$ ed, 1997) 105.

${ }^{66}$ See Blore, above n 2, 58-64. 
advocates. In sum, they are 'build[ing] discourses not in order to arrive at truth, but to win'.67

It may seem radical to say that these fatalists are aware - even subconsciously or unconsciously — that they are deploying rhetoric in order to engineer truth. However, there are a few candid moments that reveal insight into just this from at least some fatalists. Thus, Evan Wolfson, a law reform activist in the United States, says that when he began agitating for marriage equality, '[o]ne of the very first tasks I set myself was to make people believe we could and would win, that triumph was inevitable'. ${ }^{68}$ It might be said that he was trying to fashion belief rather than truth, but if we are dealing in contingent truths then the difference is only one of degree. It is also clear that fatalists have identified the same tactic behind the counter-rhetoric of their opponents. In mid-2012, in the lead-up to a parliamentary vote on same-sex marriage, the right faction of the Australian Labor Party used rhetoric to the effect that marriage equality was doomed to fail. Faced with their own inevitability rhetoric being used against them, Australian Marriage Equality responded by issuing a media release, in which it quoted its national convener, Alex Greenwich, as saying that “"myth-making” about the inevitable failure of marriage equality is just another ploy by those opposed to reform who are trying to create a "self-fulfilling prophecy", ${ }^{69}$ When advocates for equality speak of inevitability in enthymematic terms, it is difficult for them to resist the same charges of creating self-fulfilling prophecies and myth-making (or more to the point, truth-making). Of course, truth-making is happening even when reasons are given for inevitability because the struggle for domination and power at the root of truth is still playing out, but the dynamic is most obvious when the truth-claim about inevitability is supported by nothing more than assertion.

\section{B Mechanical Explanation: Cause and Effect}

Most declarations of inevitability cannot be explained away so cynically, because more often than not a reason is provided or one can be inferred from the context. Some of these reasons are based on the idea of causation - that

\footnotetext{
${ }^{67}$ Michel Foucault, 'La vérité et les formes juridiques' in Daniel Defert, François Ewald and Jacques Lagrange (eds), Dits et écrits: 1954-1988 (Gallimard, 1994) vol 2, 538, 632, quoted and translated in O'Farrell, above n 61, 66.

${ }^{68}$ Evan Wolfson, 'Is the Freedom to Marry Inevitable?' (Martin Luther King Jr Keynote address at University of Michigan Law School, 17 January 2011) <http://freemarry.3cdn.net/ 02b8d3a283f544cec6_txm6bns9g.pdf>.

${ }^{69}$ Australian Marriage Equality, Marriage Equality Support Set to Increase/Labor Right Betrays Own Grass Roots (19 June 2012) <http://www.australianmarriageequality.com/wp/ 2012/06/19/marriage-equality-support-set-to-increase-labor-right-betrays-own-grass-roots/>.
} 
the achievement of equality some time in the future will be the effect of certain causes we can detect now. ${ }^{70}$ From the review of Speak Now and the articles linked to the Australian Marriage Equality website, it appears that one of the most common causation-based explanations for why people think equality is inevitable is that they have adduced as much from reading opinion polls. For instance, Tim Wilson's chapter in Speak Now draws a clear link between the growing sense of inevitability and an analysis of opinion polls. After repeating the oft-quoted statistic that roughly two-thirds of all Australians are in favour of legalising same-sex marriage, he looks at the generational dynamic to emphasise that the trend is set to continue:

Polling focusing on the attitudes of young Australians delivers support levels around the 74 per cent mark. Unsurprisingly, faced with this reality, three-quarters of all Australians also now see marriage being extended to same-sex couples as inevitable. ${ }^{71}$

That is, existing higher levels of support among younger people will cause higher levels of overall community support in the future, which in turn will cause the eventual recognition of equality by the law. The causal nexus between each step is far from airtight - people may change their stance as they age and majority support does not guarantee that the law will be changed - but the gap between those who support marriage equality and those who think it is inevitable shows that even opponents to change feel powerless to stop this chain of causation or one like it.

If one accepts that equality is in the process of being caused, then positive opinion polls are likely to be mere symptoms of the deeper shifts in societal mores that are actually catalysing change. Intricate theories of causation try to explain these deeper dynamics at play. An example of such a theory is 'demosprudence', developed by American legal scholars Gerald Torres ${ }^{72}$ and Lani Guinier, ${ }^{73}$ and adapted to the Australian context by Adiva Sifris in order to explore the impetuses for law reform with respect to lesbian parenting. ${ }^{74}$

\footnotetext{
${ }^{70}$ Aristotle, above n 60, 'Metaphysics', 1600 (s 1013a 29): ‘[T]he maker [is the] cause of the thing made and the change-producing of the change'.

${ }^{71}$ Tim Wilson, 'Respecting Diversity and Rights' in Victor Marsh (ed), Speak Now: Australian Perspectives on Same-Sex Marriage (Clouds of Magellan, 2011) 237, 238 (emphasis in original).

${ }^{72}$ See Gerald Torres, 'Some Observations on the Role of the Social Change on the Courts' (2006) 54 Drake Law Review 895; Gerald Torres, 'Legal Change’ (2007) 55 Cleveland State Law Review 135.

${ }^{73}$ See Lani Guinier, 'Demosprudence through Dissent' (2008) 122 Harvard Law Review 6; Lani Guinier, 'Courting the People: Demosprudence and the Law/Politics Divide' (2009) 89 Boston University Law Review 539.

${ }^{74}$ Sifris, above n 40 .
} 
Demosprudence is a way of analysing the dynamics of legal change by focusing upon 'the relationship between social movements and legal change and the obverse relationship between legal change and social movements'. ${ }^{75}$

As Sifris sums up the idea of demosprudence:

It is suggested that a circular process evolves, with the precursor to cultural and legal change arising from a subtle movement on the demographic landscape. This process is reinforced with either amendments to the law or other demosprudential forces. Inevitably, there is a change in societal attitudes which results in further legal and demographic movement. In reality these elements work in tandem. Social change pulls, the law and the law pushes society [sic]. ${ }^{76}$

The central claim of demosprudence is that the twin forces of legal change and social movement are mutually reinforcing. The law cannot change without a shift in culture, ${ }^{77}$ but equally a shift in culture can be brought about by a change to the law. This is because society simultaneously creates and follows norms. This may seem paradoxical at the macro level of change. For example, decriminalisation of homosexuality could not have occurred until societal attitudes about homosexuality changed, but societal attitudes could not have changed until homosexuality was decriminalised. However, demosprudence holds that there is no such contradiction on a micro level because each incremental shift is so subtle. Each miniscule shift in culture sparks a shift in rules which in turn sparks a further shift in culture, over and over again in a recursive cycle until we see substantive transformations such as the decriminalisation of homosexuality or majority support for same-sex marriage.

Turning to the macro level of change, Kees Waaldijk's 'standard sequence' theory and William Eskridge's 'step-by-step' theory both posit that certain common markers of macro-change can be pinpointed along a chain of microcausation towards equality for lesbian and gay people. That is, we may not be able to see all of the causal steps, but there are a few landmark stages that we are able to observe, such that we can use them to measure and analyse change.

Waaldijk first articulated his hypothesis of a 'standard sequence' towards equality for lesbian and gay people in an article in $1994 .^{78}$ He sought to

\footnotetext{
75 Torres (2006), above n 72, 895.

${ }^{76}$ Sifris, above n 40, 22-3.

77 See Thomas B Stoddard, 'Bleeding Heart: Reflections on Using the Law to Make Social Change’ (1997) 72 New York University Law Review 967, 977-8.

${ }^{78}$ Kees Waaldijk, 'Standard Sequences in the Legal Recognition of Homosexuality — Europe's Past, Present and Future’ (1994) 4 Australasian Gay and Lesbian Law Journal 50. For a recent global version of this theory, see Kees Waaldijk, 'Legal Recognition of Homosexual
} 
discern a pattern from the chaos of data he had collected of the myriad ways in which European jurisdictions discriminated against and protected homosexuals. Looking at the information comparatively and over a period of time, Waaldijk came to the conclusion that

[t]here seems to be a general trend of progress; where there is legal change it is change for the better. Countries are not all moving at the same time and certainly not at the same speed, but they are moving in the same direction - forward. $^{79}$

More than just that, Waaldijk identified a common way of moving forward:

The law in most countries seems to be moving on a line starting at (0) total ban on homo-sex, then going through the process of (1) the decriminalisation of sex between adults, followed by (2) the equalisation of ages of consent, (3) the introduction of anti-discrimination legislation, and (4) the introduction of legal partnership. A fifth point on the line might be the legal recognition of homosexual parenthood. ${ }^{80}$

This is the same five-stage model recently embraced in the introductory article of the Law in Context special edition. ${ }^{81}$ However, there is an important limit to the model - one that Waaldijk himself acknowledged. He noted that not all countries follow the 'general (and logical) order of steps'; 82 indeed, '[o]ccasionally, a country takes a step backwards'. ${ }^{3}$ However, he stopped short of interrogating these anomalies. Moreover, Waaldijk never explicitly postulated what the logic of the 'standard sequence' is, save that it is not 'some "law of nature" prescribing the same specific sequences of steps in all countries (of Europe)'. ${ }^{84}$

Orientation in the Countries of the World: A Chronological Overview with Footnotes' (Paper presented at The Global Arc of Justice - Sexual Orientation Law around the World, Los Angeles, 11-14 March 2009). For a specific example of the model, see Kees Waaldijk, 'Small Change: How the Road to Same-Sex Marriage Got Paved in the Netherlands' in Robert Wintemute and Mads Andenaes (eds), Legal Recognition of Same-Sex Partnerships: A Study of National, European and International Law (Hart Publishing, 2001) 437. See also Jenni Millbank, "Which, Then, Would Be the "Husband" and Which the "Wife"?: Some Introductory Thoughts on Contesting "the Family" in Court' (1996) 3(3) Murdoch University Electronic Journal of Law 1.

${ }^{79}$ Waaldijk (1994), above n 78, 51.

${ }^{80}$ Ibid 51-2.

${ }^{81}$ Gerber and Sifris, above $n 37$.

${ }^{82}$ Waaldijk (1994), above n 78, 52.

${ }^{83}$ Ibid.

${ }^{84}$ Ibid 64. 
William Eskridge has extended Waaldijk's theory in order to delve into this logic of progress. Eskridge's reading of history begins with urbanisation. ${ }^{85}$ As populations grow and cities emerge from towns, minorities - including sexual minorities - become sufficiently concentrated for subcultures to flourish. Urban life also discourages large families, which frees up time for women to pursue roles outside of child-rearing, thereby undermining traditional gender roles. As population growth declines, sex is also defined less as procreative and more as pleasurable. Once a population is sufficiently urbanised, the stage is then set for the pattern of legal change identified by Waaldijk and which Eskridge calls 'a step-by-step process'. ${ }^{86}$ According to Eskridge, '[s]uch a process is sequential and incremental: it proceeds by little steps that are taken in a particular order' ${ }^{87}$ First, the decriminalisation of homosexuality acclimatises the wider public to the existence of lesbian and gay people and empowers more to come out of the closet. As anti-gay mindsets adjust and increasing numbers of lesbian and gay people demand rights, the public becomes increasingly likely to acquiesce to antidiscrimination laws. The further normalisation of homosexuality pushes public opinion and lawmakers to pragmatically recognise the existence of same-sex relationships and then perhaps to symbolically recognise their equal validity by permitting same-sex marriage.

In predicting equality for lesbian and gay people, all of these theories are based on the extrapolation of perceived trends. Sifris claims that microchanges in social, political and economic factors 'have converged to create the momentum for ... the social and legal recognition of the lesbian-led family' ${ }^{88}$ Eskridge has similarly added micro-changes as flesh to the skeleton provided by Waaldijk to claim that marriage equality is nigh in most Western nations. No doubt, current events will have some impact upon future events. For example, given that older people tend to oppose same-sex marriage, as they die, average levels of support for marriage equality will very probably increase, at least in the near future. However, these theorists are reaching even further than the imminent future into the inherently uncertain realm of the more distant future. The further into the future they attempt to foresee, the murkier the image becomes because the possibility of random disruptions to causal connections becomes more and more likely. ${ }^{89}$ Further, the existing

\footnotetext{
${ }^{85}$ William Eskridge, 'Comparative Law and the Same-Sex Marriage Debate: A Step-by-Step Approach toward State Recognition’ (2000) 31 McGeorge Law Review 641, 655-6.

${ }^{86}$ Ibid 647.

${ }^{87}$ Ibid 647-8.

${ }^{88}$ Sifris, above n 40, 23.

${ }^{89}$ Popper, above n 52, 115. For Karl Popper, the reason for this is that scientifically predictions may only be based on laws (which do not exist in history) and never trends. See also at 117 regarding the sequence of multiple causally connected concrete events.
} 
trends informing their conclusions of equality are so broad ${ }^{90}$ and so microscopic $^{91}$ that no direct causal claims can be made, ${ }^{92}$ suggesting that authors such as Waaldijk and Eskridge have conveniently imposed order on the past through hindsight rather than discovered an inevitable chain of causation. Seen in this light, the conclusion of inevitability may in fact be the cumulation of a series of microscopic leaps of faith rather than microscopic causal connections. ${ }^{93}$ It is all the more suspicious that these leaps of faith lead to a convenient endpoint: equality. This is not to say that the inability to show direct causation is proof that there is no causation whatsoever - there is every chance that something indirect is going on - but it might also be that Sifris, Waaldijk and Eskeridge started with a teleological conclusion and worked backwards to a theory of causation

Two further features of these theories hint at a teleological streak. The first is that there is little or no room in each of these models for backward steps. As Eskridge acknowledged of his step-by-step theory, 'each step in the process is a step toward formal equality' ${ }^{94}$ and '[a] skeptic can reasonably object that this is the sort of progressive, whiggish approach to history that has repeatedly been undone by the unpredictability of human events'. ${ }^{95}$ Waaldijk, for his part, dealt with the difficulty of reconciling instances of regression by ignoring them completely. ${ }^{96}$ Demosprudence, on the other hand, has dealt with countertrends away from equality with somewhat more sophistication. The existence of countertrends and backlashes are readily acknowledged as long as they provoke an even greater swing back towards equality — what Torres terms a 'blessing in disguise' ${ }^{97}$ and Guinier the 'zigzag trajectory of change'. ${ }^{98}$ Thus the 15-year period of constant defeat suffered by campaigners for anti-discrimination laws in New York was in fact positive because it allowed the acceptance of homosexuality to be acculturated in advance of the

\footnotetext{
${ }^{90}$ Guinier (2009), above n 73, 554: 'the river of social change has many tributaries'.

91 As John Stuart Mill put it, although there are historical laws and history is therefore predictable, the problem is that it involves '[s]o long a series of actions and reactions ... each successive term being composed of an ever greater number and variety of parts, [that historical predictions] could not possibly be computed by human faculties from the elementary laws which produce it’: John Stuart Mill, A System of Logic: Ratiocinative and Inductive (Longmans, 1947, first published 1843) 597 (book VI ch X s 4).

92 Torres expressly disavows that demosprudence is capable of making such claims: Torres (2006), above n 72, 897; Torres (2007), above n 72, 136.

93 See Rosenberg's criticism of Guinier's demosprudence on a similar basis: Gerald N Rosenberg, 'Romancing the Court' (2009) 89 Boston University Law Review 563, 565-9.

${ }^{94}$ Eskridge, above n 85, 654.

95 Ibid 655.

${ }^{96}$ Waaldijk (1994), above n 78, 52.

${ }^{97}$ Torres (2006), above n 72, 901.

${ }^{98}$ Guinier (2009), above n 73, 543.
} 
law. ${ }^{99}$ In the same vein, in Australia, 'the negative publicity resulting from the former Howard government's reluctance to legislate in respect of same-sex families stimulated the public's interest', thereby allowing legislative gains to be made down the track. ${ }^{100}$ Even for demosprudence, there are no permanent backward steps.

The second feature of these theories that belies their true teleological inspiration is that they have an endpoint. For Sifris it is the full recognition of lesbian-led families. For Waaldijk and Eskridge, the trajectory that they see as inevitable (at least in parts of the West) appears to end abruptly in marriage equality. As one critic put it, the suggestion is 'that to prevail on same-sex marriage is to prevail finally'. ${ }^{101}$ We are left to infer that the dynamics behind the inertia towards equality will suddenly become static once equality is achieved. In all of these theories there is no imagining of a post-equal world. As to why this might be, we turn to the third and final explanation for these statements of inevitability: a blind belief in the idea of progress.

\section{Teleological Explanation: Equality as the Purpose of History}

It seems that G W F Hegel is on the tip of these theorists' tongues. Hegel's ideas may be almost 200 years old, but they seem to be well and truly alive in the assumptions imbuing many of the statements of inevitability uncovered in the first part of this article. Indeed, we saw Kerryn Phelps invoking the Hegelian notion of the Zeitgeist at the Sydney Mardi Gras. ${ }^{102}$ In fact, most statements of inevitability involve a subtle teleological component, in that they involve explanations of phenomena by reference to a purpose. ${ }^{103}$ This is most evident when progress is treated as a law of history rather than the chance effect of a constellation of causes. Even causal reasoning which starts with existing trends and ends in equality is likely unscientific; except for cautiously phrased predictions of the very near future, this reasoning is a bridge too far for logic. This kind of reasoning must begin with the conclusion of equality and work backwards to selecting facts that confirm the belief. ${ }^{104}$ This is teleology par excellence - starting with the purpose of history and then coming up with laws of history, such as progress, to get us there. Given Hegel's reach beyond the grave, while he is notoriously difficult to pin down,

\footnotetext{
99 Torres (2006), above n 72, 901; Stoddard, above n 77, 981-2.

100 Sifris, above n 40, 22.

${ }^{101}$ Libby Adler, 'The Gay Agenda’ (2009) 16 Michigan Journal of Gender and Law 147, 187.

102 Phelps, above $n 20$.

103 Aristotle, above n 60, Metaphysics, 1600 (s 1013a 29) (formal-final cause).

104 On the tendency of metaphysical theories to do this, see Popper, above n 52, 111.
} 
his ideas about history are useful in explaining this popular sense of inevitability. At the root of his philosophy is the same belief in historical development as something inevitable and progressive. ${ }^{105}$

Fundamental to Hegel's thesis of universal history is the principle that ' $[t]$ he History of the world is none other than the progress of the consciousness of Freedom'. ${ }^{106}$ To understand what Hegel meant by this we need to begin with his assertion that history is rational. He wrote that 'Reason is the Sovereign of the World [and] that the history of the world, therefore, presents us with a rational process'. ${ }^{107}$ If history is rational then it cannot happen by chance in a series of random events; it must play out pursuant to certain laws. According to Hegel, some of these laws are mechanical, explaining events by pointing to prior causes in time (the notion of causation that we have already explored), and others are teleological, accounting for events by their underlying purpose or design. ${ }^{108}$ Thus to say there is reason in history is to say that events happen of necessity to realise a purpose. ${ }^{109}$ As to what this purpose is, Hegel pointed to the inherent form or essence of humankind which, he posited, is freedom. ${ }^{110}$ When he said that humans are by their nature free, he did not mean that we are born free, ${ }^{111}$ or that we are free in some state of nature. ${ }^{112}$ Freedom is not a gift bestowed on us, but rather our goal that we must strive to achieve. ${ }^{113}$ Since realisation of this goal involves a process, it can only be

\footnotetext{
${ }^{105}$ Frederick Beiser, Hegel (Routledge, 2005) 262. There are, of course, other philosophers with a progressivist/teleological view of history. See, eg, Mill, above n 91, 595-7 (book VI ch X s 3); Auguste Comte, The Positive Philosophy of Auguste Comte (Harriet Martineau trans, Trübner \& Co, 1875, $2^{\text {nd }}$ ed) vol 2 [trans of: Cours de philosophie positive (first published 1830-1842)] (the idea that the law of the progress of history can be deduced from the progressiveness of the human mind).

${ }^{106}$ G W F Hegel, The Philosophy of History (J Sibree trans, Willey Book Co, 1944) 19 [trans of: Vorlesungen über die Philosophie der Weltgeschichte (first published 1837)].

${ }^{107}$ Ibid 9.

${ }^{108}$ G W F Hegel, Hegel's Science of Logic (A V Miller trans, George Allen \& Unwin, 1969) 711-26 (mechanical laws), 734-54 (teleological laws) [trans of: Wissenschaft der Logik (first published 1831)].

${ }^{109}$ Hegel, above n 106, 19-20, 56.

${ }^{110}$ Hegel, above n 106, 17-8; G W F Hegel, Elements of the Philosophy of Right (H B Nisbet trans, Allen W Wood ed, Cambridge University Press, 1991) 35-7 (§ 4) [trans of: Grundlinien der Philosophie des Rechts (first published 1821)].

111 Cf Jean-Jacques Rousseau, The Social Contract and Discourses (G D H Cole trans, Everyman, 1993) 181 [trans of: Du contrat social (first published 1762)]: 'Man is born free; and everywhere he is in chains'.

${ }^{112}$ Cf John Locke, The Second Treatise of Government (J W Gough ed, Basil Blackwell, first published 1690, 1966 ed) 4: 'a state of perfect freedom [in which people can] order their actions and dispose of their possessions and persons as they think fit, within the bounds of the law of nature, without asking leave, or depending upon the will of any other man'.

${ }^{113}$ Hegel, above n 106, 40-1.
} 
attained through the passage of time, that is, in history. ${ }^{114}$ It did not matter to Hegel that the individuals who act out history are unaware of this purpose of realising freedom. Hegel used the idea of the 'cunning of reason' (List der Vernunft) - much like Adam Smith's idea of the 'invisible hand,115 — to contend that reason uses people's self-interests to realise its own ends. ${ }^{116}$ Thus freedom is being actualised by the unwitting actions of individuals in the relentless march of history. But not only is freedom being actualised; it is also coming to an awareness of itself in the process. ${ }^{117}$ The regimes of knowledge being formed through the historical process ${ }^{118}$ are arriving at the insight that 'man, as such, is free'. ${ }^{119}$ According to Frederick Beiser, this self-awareness of freedom also embodies the idea of equality:

Hegel argues that my self-awareness as a free being must be social or intersubjective. It demands the recognition of others as equal and independent beings because only by this means do I achieve the recognition necessary to confirm to myself that I too am an independent being. ${ }^{120}$

In Hegel's words, self-awareness of freedom is the "I" that is "We" and "We" that is "I"'. ${ }^{121}$ Thus, the end of history is the realisation of a state in which there is a community between free and equal individuals. ${ }^{122}$ The struggle of lesbian and gay liberation - to be treated as equal and independent beings — is but one subplot along this path towards freedom.

Before trying to cross-examine Hegel, it is necessary to lay out his mechanics of progress, for it is here that his theory becomes undisprovable. ${ }^{123}$ Hegel

\footnotetext{
114 Ibid 72.

115 Adam Smith, An Inquiry into the Nature and Causes of the Wealth of Nations (R H Campbell and A S Skinner (eds), Clarendon Press, first published 1776, 1976 ed) vol 1, 456.

${ }^{116}$ Hegel, above n 106, 20-6, 32-3.

117 Ibid 19.

118 Ibid 53.

119 Ibid 18.

120 Frederick C Beiser, 'Hegel's Historicism' in Frederick C Beiser (ed), The Cambridge Companion to Hegel (Cambridge University Press, 1993) 270, 292.

${ }^{121}$ G W F Hegel, The Phenomenology of Spirit (A V Miller trans, Oxford University Press, 1977) 110 [trans of: Phänomelogie des Geistes (first published 1807)].

122 Beiser, above n 120, 293. Cf Francis Fukuyama, The End of History and the Last Man (The Free Press, 1992) 313-21 (for whom the liberal democracies standing at the end of history must tolerate a level of inequality).

${ }^{123}$ In case there are any diehard Hegelians reading this, the caveat applies that the following is a popular bowdlerisation of Hegel's dialectical method: see Gustav E Mueller, 'The Hegel Legend of "Thesis-Antithesis-Synthesis"' in Jon Stewart (ed), The Hegel Myths and Legends (Northwestern University Press, 1996) 301. Nonetheless it is perhaps the shortest route to gaining an insight into Hegel and it 'does capture the intended general structure of the method
} 
argued that a dialectical relationship governs the evolution of freedom. ${ }^{124}$ First, you have a thesis - for example, in 2003 the Family Court of Australia recognised the validity of the marriage between a woman and a transsexual male, thereby throwing open the idea that marriage need not be defined by gender or sexuality. ${ }^{125}$ But as a thesis loses its original traction in society it sows the seeds of its own destruction. In this way it negates itself in the form of an antithesis or differentiation. In this example, the Howard government amended the Marriage Act 1961 (Cth) to redefine marriage as exclusively heterosexual, ${ }^{126}$ and successive politicians reinforced this position. Destruction, suffering and evil are necessary in this view for otherwise we could not have regeneration. ${ }^{127}$ For Hegel, regressive steps represent freedom alienating itself — a kind of metaphysical inner-division of the guiding spirit of history - but he saw this as a necessary precondition for re-incorporating the other into itself again or self-realisation which is the purpose of history. ${ }^{128}$ Thus, to continue with the above example, civil partnership regimes that have arisen in some Australian states and territories reconcile the need to acknowledge relationships with the privileging of marriage as a heterosexual institution. This unity-in-difference or synthesis then gives rise to its own antithesis - perhaps a renewed push for marriage equality as has recently succeeded in the UK. ${ }^{129}$ This cycle of thesis, antithesis and then synthesis continues, but in a self-transcendent way so that freedom is constantly engaged in an 'ascent to an ever higher concept of itself' . ${ }^{130}$

It seems that the easiest way to discredit a theory of progress towards equality is to point to countertrends away from that endpoint. There are many examples of such regression that activists for equality have failed to weave into their statements of inevitability. For example, in 2012 the Queensland government established a precedent of reversing symbolic equality gains when it abolished state-sanctioned civil unions, leaving only the bare entitlement to register a relationship. ${ }^{131}$ In the process, the Queensland

reasonably well': Michael Forster, 'Hegel's Dialectical Method' in Frederick C Beiser (ed), The Cambridge Companion to Hegel (Cambridge University Press, 1993) 130, 131.

${ }^{124}$ Beiser, above n 105, 114-5; Hegel, above n 106, 56-7.

${ }^{125}$ A-G (Cth) v Kevin (2003) 172 FLR 300.

${ }^{126}$ Marriage Act 1961 (Cth) s 5 (definition of 'marriage'), amended by Marriage Amendment Act 2004 (Cth) s 1.

${ }^{127}$ Hegel, above n 106, $26-7$ ('Periods of happiness are blank pages in [history], for they are periods of harmony - periods when the antithesis is in abeyance'), 72-3.

${ }^{128}$ Hegel, above n 106, 26, 55, 78.

${ }^{129}$ See Marriage (Same Sex Couples) Act 2013 (UK) c 30.

130 Jeffrey A Gauthier, Hegel and Feminist Social Criticism (State University of New York Press, 1997) 166 (quoting a translation of a different edition of Hegel, above n 106).

${ }^{131}$ The Civil Partnerships Act 2011 (Qld) became the Relationships Act 2011 (Qld) with the passing of the Civil Partnerships and Other Legislation Amendment Act 2012 (Qld). For the 
Attorney-General threatened to also repeal 'the provisions in the Surrogacy Act that deal with same-sex couples'. ${ }^{132}$ However, Queensland is far from the only jurisdiction to prove that devolution is possible. Victoria tinkered with its anti-discrimination legislation in 2011 in order to enlarge the areas of activity in which lesbian and gay people may legitimately be discriminated against. ${ }^{133}$ Internationally, several American states have reversed marriage equality gains at the ballot box, most infamously by means of Proposition 8 in California (although that particular example was ultimately unsuccessful). ${ }^{134}$ In spite of Russia decriminalising homosexuality in $1993,{ }^{135}$ in recent years nine regions enacted anti-proselytisation laws under which lesbian and gay people have been arrested for such trivial acts as holding a sign reading 'Homosexuality is

political impetuses see Edmund Robinson, 'Same-Sex Partnerships in Queensland' (2012) 37(1) Alternative Law Journal 63; Allan Ardill, 'A New Era in Queensland Politics' (2012) 37(3) Alternative Law Journal 208, 208-9. For the social impetuses see Michael Flood and Clive Hamilton, 'Mapping Homophobia in Australia' in Shirleene Robinson (ed), Homophobia: An Australian History (Federation Press, 2008) 17; Shirleene Robinson and Alan Berman, Speaking Out: Stopping Homophobic and Transphobic Abuse in Queensland (Australian Academic Press, 2010).

132 Queensland, Parliamentary Debates, Legislative Assembly, 21 June 2012, 994 (Jarrod Bleijie, Attorney-General). See also Malcolm K Smith et al, 'Back to the Future: Prohibiting Surrogacy for Singles, Same-Sex and Shorter-Term Heterosexual Couples in Queensland' (2013) 20 Journal of Law and Medicine 638.

133 Equal Opportunity Act 2010 (Vic) ss 82(2), 83(2), amended by the Equal Opportunity Amendment Act 2011 (Vic), ss 18-19. See also John Tobin, 'Should Discrimination in Victoria’s Religious Schools Be Protected? Using the Victorian Charter of Human Rights and Responsibilities Act to Achieve the Right Balance' (2011) University of Melbourne Legal Studies Research Paper No 564.

${ }^{134}$ On Proposition 8 specifically, see Hollingsworth $v$ Perry, 570 US _ (2013) in which the Supreme Court held that petitioners opposing same-sex marriage did not have standing to appeal from the District Court to the Ninth Circuit. Accordingly the Ninth Circuit decision in Perry v Brown, 671 F 3d 1052 (2012) was vacated, leaving in place the District Court decision of Perry $v$ Schwarzenegger, 704 F Supp 2d 921 (ND Cal, 2010) which had declared Proposition 8 unconstitutional. See also Re Marriage Cases, 43 Cal $4^{\text {th }} 757,829$ (Cal, 2008) which sparked Proposition 8. On state Defense of Marriage Acts generally, see Baehr v Lewin 852 P2d 44 (Haw, 1993); Stoddard, above n 77, 987-8; Patrick J Borchers, 'The Coming Collision: Romer and State Defense of Marriage Acts' (2008) Brigham Young University Law Review 1635; Charles E Mauney Jr, 'Landmark Decision or Limited Precedent: Does Lawrence v Texas Require Recognition of a Fundamental Right to Same-Sex Marriage?' (2005) 35 Cumberland Law Review 147, 153 n 27; Michael T Morley et al, 'Developments in Law and Policy: Emerging Issues in Family Law’ (2003) 21 Yale Law and Policy Review 169, 188-9. Note that the recent Supreme Court decision of United States $v$ Windsor, 570 US (2013) dealt with one aspect of the federal Defense of Marriage Act, 110 Stat 2419 without affecting state Defense of Marriage Acts.

135 Immigration and Refugee Board of Canada, Russia: Update to RUS13194 of 16 February 1993 on the Treatment of Homosexuals (29 February 2000) <http://www.unhcr.org/refworld/ docid/3ae6ad788c.html>. 
Normal', ${ }^{136}$ and in 2013 these laws were nationalised. ${ }^{137}$ Uganda is notorious for its draconian efforts to increase penalties for homosexuality, ${ }^{138}$ which, if successful, would signify a regression before there has been any progress from which to regress. However, the beauty of Hegel's historicism is that all of these worrying trends are not only consistent with the idea of progress, they are prerequisites for progress. They are the 'blessings in disguise' marking the 'zigzag trajectory' of the development of equality. No matter how oppressive the countertrends may be, Hegelians will reply that in the fullness of time an even greater equality will arise from the ashes of inequality. One cannot definitively say that the future will not eventually evolve in this way and so the assumption that history is progressive 'can never finally be refuted'. ${ }^{139}$

Irrefutability is not the end of the matter, however. When it comes down to a matter of belief, as it does here, one may still be able to say whether one proposition is more or less likely than some other proposition. At this point it is necessary to reintroduce Foucault who also dealt with regression in history, but who came to a radically different conclusion to Hegel. Foucault was mentioned above for his contention that truth is discursively constructed. What was not said is that he had a penchant for using history to prove this. ${ }^{140}$ For instance, he famously debunked the immutability of sexuality by showing that it has a history; that 'the homosexual' did not register in our lexicon of ideas in the distant past and therefore is not an innate category of person. ${ }^{141}$ Thus in order to lay bare the limits of entire systems of thought, Foucault

136 'Discrimination in Russia: Arrests for Violation of St. Petersburg Anti-Gay Law', Spiegel (online), 6 April 2012 <http:/www.spiegel.de/international/world/two-arrested-in-st-peters burg-for-violating-city-s-new-anti-gay-law-a-826199.html>; Miriam Elder, 'St Petersburg Bans "Homosexual Propaganda", The Guardian (online), 12 March 2012 <http://www. guardian.co.uk/world/2012/mar/12/st-petersburg-bans-homosexual-propaganda>.

137 Bonnie Malkin (ed), 'Vladimir Putin Signs Anti-Gay Propaganda Bill', The Telegraph (online) 30 June 2013 <http:www.telegraph.co.uk/news/worldnews/europe/russia/10151790/ Vladimir-Putin-signs-anti-gay-propaganda-bill.html $>$.

138 Anti-Homosexuality Bill 2009 (Uganda) cl 3 (offence of 'aggravated homosexuality' punishable by death). For the social impetuses leading to the bill see Michael Hollander, 'Gay Rights in Uganda: Seeking to Overturn Uganda's Anti-Sodomy Laws’ (2009) 50 Virginia Journal of International Law 219, 220-6. For the political impetuses see Xavier B Lutchmie Persad, 'Homosexuality and Death: A Legal Analysis of Uganda's Proposed AntiHomosexuality Bill’ (2010) 6 Florida A \& M University Law Review 135, 136-40.

139 Larry Krasnoff, Hegel's Phenomenology of Spirit: An Introduction (Cambridge University Press, 2008) 157. Note though that, for Karl Popper, the fact that this hypothesis cannot be tested renders it valueless: Popper, above n 52, 151.

140 Michel Foucault, 'Truth, Power, Self: An Interview with Michel Foucault, October 25, 1982' in L Martin, H Gutman and P Hutton (eds), Technologies of the Self: A Seminar with Michel Foucault (University of Massachusetts Press, 1988) 9, 11.

${ }^{141}$ Foucault, Will to Knowledge, above n 64, 43. 
emphasised the ruptures, discontinuities and ceaseless change that characterise history.

Foucault drew two lessons from these aspects of history. The first is to be wary of narratives of continuity. For him, '[t]he traditional devices for constructing a comprehensive view of history and for retracing the past as a patient and continuous development must be systematically dismantled' ${ }^{142}$ Assumptions of continuity need to be challenged in Foucault's view because they tend to downplay and erase instances of discontinuity, and if this is happening then history is being rewritten to fit a particular preconceived image of it. Certainly, in the discourse of inevitability, we have seen the sidelining of countertrends away from equality. It is difficult to find examples from popular culture of a statement of inevitability which simultaneously acknowledges regression. ${ }^{143}$ Even academic commentators such as Waaldijk and Eskridge - though they have conceded that there are backward steps have essentially ignored them as irrelevant to their theories of progress. It might be said that Hegel's historicism escapes this criticism because he in fact embraces discontinuities as the preconditions for further progress - they are the antitheses or blessings in disguise. But for Foucault, subsuming discontinuity within a broader prediction of continuity is nothing more than a sleight of hand. This is because doing so relies on a whole host of metaphysical beliefs which cannot be verified by experience, not least of which is a belief that regression cannot continue ${ }^{144}$ even though hypothetically we know it might.

The second lesson that Foucault takes from discontinuity is that the future is unpredictable. On Clare O’Farrell's reading of Foucault, he

argues that we can only examine a system of discourse, an archive, once it has already happened. We cannot extrapolate from one specific historical order and say that a particular rule will be valid tomorrow or next year. One can only describe the rules of a past system of discourse, we cannot make those rules prescriptive and apply them in the future. ${ }^{145}$

\footnotetext{
${ }^{142}$ Michel Foucault, 'Nietzsche, Genealogy, History' in Michel Foucault, Language, CounterMemory, Practice: Selected Essays and Interviews (Donald Bouchard and Sherry Simon trans, Cornell University Press, 1977) 139, 153.

${ }^{143}$ See, eg, Tiffany Jones, 'Tying the K(Not)!' in Victor Marsh (ed), Speak Now: Australian Perspectives on Same-Sex Marriage (Clouds of Magellan, 2011) 105, 109: 'We waited ten years after our engagement, but the law didn't evolve. It devolved.'

${ }^{144}$ Hegel, above $\mathrm{n} 106,16$. Hegel asserts that 'evil has not been able permanently to assert a competing position'.

${ }^{145}$ O’Farrell, above n 61, 78.
} 
It is perhaps too much to say that one can never extrapolate into the future, ${ }^{146}$ but of present interest is Foucault's reason for refusing to delve into the future. For him, the future cannot be divined because, as much as there might be cause and effect in history, there is also chance. ${ }^{147}$ Allowing for random events is pivotal because it strikes at the assertion that history is rational. If we accept that history might be irrational then all of Hegel's teleology built upon that bedrock assertion ${ }^{148}$ comes tumbling down. One cannot hold simultaneously that all things happen for a reason but that some things might happen for no good reason at all.

In the end, there is a choice between believing that history is rational and believing that it is irrational, neither of which can be definitively proved or disproved. In trying to decide which is more likely to be the case, it is important to point out that the history-as-irrational thesis has less to prove. On this view, history simply happens and we passively experience historical phenomena as isolated events without the need for positive beliefs to make sense of them. We have only the absence of belief. On the other hand, a rationalist view of history does require us to positively believe certain things, for example that everything has a purpose and that things will get better. In this sense progressivists bear the onus of showing why we should actively believe anything at all, let alone what they believe. Believing in the absence of something is still a belief and therefore one must ultimately be agnostic about history, but even so, it is more likely than not that we would be making things up if we were to believe that history plays out according to magical formulae. It follows that equality for lesbian and gay people probably is not inevitable, at least in a teleological sense, though no one can say for certain.

As to why lesbian and gay law reform advocates nonetheless subscribe to inevitability, Immanuel Kant pointed out as long ago as the $18^{\text {th }}$ century that human reason is tortured by questions it can neither answer nor ignore. ${ }^{149}$ When we face questions that we cannot solve by reference to experience, 'we would rather venture everything, even at the risk of erring, than give up' ${ }^{150}$ Nowadays evolutionary psychologists likewise argue that humans are

\footnotetext{
${ }^{146}$ The author agrees with Karl Popper that the argument against historicism does not 'refute the possibility of every kind of social prediction': Popper, above n 52, vii.

${ }^{147}$ O’Farrell, above n 61, 76.

${ }^{148}$ Hegel makes this foundation to his theory clear from the outset. See Hegel, above n 106, 10: 'If the clear idea of Reason is not already developed in our minds, in beginning the study of Universal History, we should at least have the firm unconquerable faith that Reason does exist there' (emphasis in original).

${ }^{149}$ Immanuel Kant, Critique of Pure Reason (Paul Guyer and Allen W Wood trans, Cambridge University Press, 1998) 99 [trans of: Kritik der reinen Vernunft (first published 1781, 1787 ed)].

${ }^{150}$ Ibid 139.
} 
hardwired to try to make sense of anything they encounter. ${ }^{151}$ The hypothesis is that inferential reasoning gave our distant ancestors the competitive edge in the contest for survival, but a by-product of this characteristic is that humans tend to automatically impose explanatory narratives on any phenomenon they come across, regardless of how random and inexplicable it is in actuality. ${ }^{152}$ The future is the ultimate unknown which the human brain feels compelled to tame. This need for certainty in the face of uncertainty is what gives rise to teleological ideas such as progress, because ideas like this allow their adherents to believe that at least the unpredictability of the future will play out predictably. As Karl Popper wrote, concluding his critique of historicism:

It almost looks as if [these fatalists] were trying to compensate themselves for the loss of an unchanging world by clinging to the faith that change can be foreseen because it is ruled by an unchanging law. ${ }^{153}$

Thus believing that history is rational may just be a way that human brains relieve their anxiety through the pretence that all the uncertainty embodied by the future is ultimately subject to something certain — if you are an optimist, something like progress.

\section{IF EqUALITY IS NOT INEVITABLE, WHERE TO FROM HERE?}

Thus far we have established that none of the reasons why people make statements of inevitability provide a solid foundation for believing their conclusions of inevitability. Rhetorical statements are based on loose logic, causal reasoning can get us safely only so far into the future and any teleological account of history is more likely than not a ruse. In the words of political theorist Wendy Brown:

We are confronted [then] with the fact of history — and so also with political futures and actions that would produce and configure them - as a sheer problem of power. This is what is brought into view at the moment that historical metanarratives are fully exposed as fictions. ${ }^{154}$

151 Richard Dawkins, The God Delusion (Houghton Mifflin Co, 2006) 179-90. For the psychological predisposition of children to teleological explanations, see Deborah Keleman, 'Are Children “Intuitive Theists”?' (2004) 15(5) Psychological Science 295.

152 See Pascal Boyer, Religion Explained: The Evolutionary Origins of Religious Thought (Basic Books, 2001) 10-19, 118-35; Lee A Kirkpatrick, Attachment, Evolution, and the Psychology of Religion (Guilford Press, 2005) 270-9; Scott Atran, In Gods We Trust: The Evolutionary Landscape of Religion (Oxford University Press, 2002) 57-61.

153 Popper, above n 52, 161.

${ }^{154}$ Wendy Brown, Politics Out of History (Princeton University Press, 2001) 42. 
When confronted with this destabilisation of the narrative of inevitability, what avenues are open to campaigners, pop culture generators and academics acting as lesbian and gay law reform activists? There are at least three.

The first is to despair and become lost in the grip of a 'paralyzing disorientation' ${ }^{155}$ For if we lose the promise of a better future - with no surefooted ideology or narrative to replace it - what reason is there to fight the good fight? On what do we pin our hopes? Even if activists do manage to continue their struggle, how are they to orient themselves without constants such as 'progress'? They will be forced to locate their law reform efforts within a history that lacks 'a landmark or a point of reference'. ${ }^{156}$ It is submitted that heightened anxiety about the future and the prospects of gaining equality is a good thing. When all bets are off and no result is preordained, there is greater incentive to exert the energy needed to effect social and legal change. The fact that the activist can no longer cling to the certainty of progress may at first be dizzying, but in the wake of deconstructed metanarratives we must all learn to 'pursue political justice within a world that is contingent, unpredictable, not fully knowable, and directed neither by external forces nor by internal logics' ${ }^{157}$ Giving up on progress can also be empowering in the sense of freeing activists from delusions and revealing to them the actual dynamics of power at play behind the discourse of inevitability.

This brings us to the second option available to gay law reform activists. With the benefit of this revelation about the hegemony of progress, they may choose to continue to exploit the discourse of inevitability, knowing all the while that it is a fiction. Essentially, if they persist with inevitability, they must do so for the cynical reason already explored above; that is, as a rhetorical device in an attempt to engineer truth through a self-fulfilling prophecy that lesbian and gay people will one day be equal. Given that humans tend naturally to think of history in teleological terms, it may be strategic to appropriate the progressive destination towards which it is said we are headed and to prescribe it as one of equality between the sexualities.

There are, however, various shortcomings to this totalising strategy, not the least of them being that the strategy is disingenuous and takes people for fools. For one thing, if the strategy succeeds and people do believe that equality is inevitable, then all except those in the know are liable to become complacent. Why work hard for equality when it is guaranteed, and if we ever do attain it, why guard it vigilantly when it is irreversible? For another thing,

\footnotetext{
${ }^{155}$ Ibid 14.

${ }^{156}$ Foucault, above n 142, 155.

${ }^{157}$ Brown, above n 154, 145.
} 
in pretending that the discourses of inevitability and progress remain intact, this cynical strategy cannot simultaneously undermine them through selfcriticism and self-reflection. It cannot ask what the effect is of the narrative of progress or how invocations of inevitability work to marginalise certain subjects and experiences. Moreover, because such a strategy is wedded to the idea of a single predestined future, it cannot deign to imagine competing futures and the limitless political possibilities that lie within them. By far the biggest drawback to the strategy is that there is no assurance it will work. Its success depends on lesbian and gay rights activists being able to ingrain the eventual achievement of equality as a self-evident given. In Foucauldian terms, this involves formulating knowledge, which requires power (though knowledge and power have a symbiotic relationship). The problem is that the power behind the ability of equality activists to formulate truth is not static. There are competing discourses on sexuality circulating in society that could begin to gain the upper hand and infiltrate knowledge structures at any moment. There is no guarantee, therefore, that power will not shift to other segments of society, as we are currently witnessing in Russia, for example. In the context of a lurch to conservatism in Russia, ${ }^{158}$ it would hardly be surprising to find that lesbian and gay rights activists there lack the power to engender a widespread belief that their equality is inevitable. At the very least, lesbian and gay rights activists should be wary of putting all their eggs in this basket.

The last option for lesbian and gay law reform activists is to move outside the framework of progress, or, as Brown puts it, to engage in a politics 'out of history'. ${ }^{159}$ As to what this post-progressivist politics might look like, ideally it should be characterised by a wild imagination as well as a deep suspicion of the present in order to release the present's hold over the future. Once equality activists appreciate that there is an infinite number of possible futures, they need to draw upon all their creativity to imagine what these futures may be. They need to conjure up utopias to provide the goals for their activism, but they also need to envisage dystopian futures so that they can be prepared for less than ideal eventualities. As Popper might have said, equality advocates need to dare to imagine the conditions under which progress will be arrested. $^{160}$ As for fomenting a deep suspicion of the present, Brown advocates taking up a 'genealogical politics' based on the concept of 'genealogy' as formulated by Nietzsche ${ }^{161}$ and adapted by Foucault. ${ }^{162}$ For

\footnotetext{
158 See Emil Pain, 'Special Characteristics of the Post-Soviet Political Regime' (2012) 50(6) Russian Politics and Law 41, 41-7.

159 Brown, above n 154, 14.

160 Popper, above n 52, 129-30.

${ }^{161}$ Friedrich Nietzsche, On the Genealogy of Morals (Walter Kaufmann and R J Hollingdale trans, Vintage, 1969) [trans of: Zur Genealogie der Moral (first published 1887)].
} 
Brown, we must call into question everything we think we know, and especially purported truths, in order to discover that 'the present [is only] the accidental production of the contingent past'. ${ }^{163}$ What we currently know as 'progress', 'equality', 'rights' and 'sexuality', for example, are all constructs of history and are thus open to being rendered mutable. When we discover, as Nietzsche did, that the present may be 'living at the expense of the future', ${ }^{164}$ we become capable of intervening and reshaping history (rather than being, as Hegel insisted, the mere tools of history ${ }^{165}$ ). Thus genealogy opens up 'faults, fractures, and fissures ${ }^{166}$ in the present, through which various futures might be pursued.

More specifically, it is to be hoped that a lesbian and gay activism 'out of history' would be as obsessed as Foucault was with discontinuities. Genealogy — as a way of viewing history that highlights discontinuity — can help shine a spotlight on countertrends away from equality and the possibility that formal equality is reversible. As we have seen, the assumption of inevitability tends to conceal the experience of growing inequality in one way or another. Tactical statements of inevitability deny the existence of countertrends, causation-based statements ignore them as irrelevant, and teleological statements trivialise them as the quaint preludes to progress as usual. Yet there are alarming trends both domestically and internationally that are not being given airspace in this discourse of inevitability. For example, the Queensland government has recently shown that symbolic equality gains can be reversed. However, rather than learning from this setback by identifying what made equality susceptible and how it might be made resilient, the discourse of inevitability has relegated the Queensland example to the status of an embarrassing anomaly that will soon be set right in the march of progress. It may be that depriving countertrends of oxygen is the key to inevitability creating its own reality. It may also be that ignoring countertrends leaves us unprepared for the future. Instead of marginalising these experiences, a lesbian and gay activism 'out of history' might draw attention to them, both to combat them in the present and to study their causes for posterity. If lesbian and gay people ever do achieve an equal status under the law, post-progressivists would be mindful that there is no 'end of history', only ceaseless unpredictable change which may include the undoing of equality in a post-equal world. By highlighting instances of regression and making a science out of the resilience or reversibility of equality, activism

\footnotetext{
${ }^{162}$ Foucault, above n 142.

163 Brown, above n 154, 103.

164 Nietzsche, above n 161, 20.

165 Hegel, above n 106, 20-6, 32-3.

166 Brown, above n 154, 103.
} 
'out of history' can help us to acquire the tools we need to face these darker days.

\section{CONCLUSION}

There is a mounting sense in Australian society - if not the entire Western world - that equality for lesbian and gay people is inevitable, and this assumption is so insidious that it is creeping into what is accepted as truth without challenge. There are a number of overlapping reasons why people might declare that equality is bound to be attained. In a political struggle over the distribution of rights in society, rhetoric and rational arguments with different bases tend to get mixed up. In teasing them out this article has delineated three possible reasons why the language of inevitability is being employed. First, those who espouse inevitability may simply be propagandising the issue of inequality. On a superficial level, it seems that the authors of these sound-bite slogans are not overly concerned with whether or not inevitability is true. On a deeper analysis, taking into account the relationship between power and knowledge, it seems that they are in fact attempting to engineer truth through self-fulfilling prophecies in order to win the debate. Second, these fatalists may be resigned to inevitability because they see a chain of causation leading to equality at some point in the future. One can make relatively safe predictions that certain causes we can detect now will have certain effects in the very near future, but formal equality for lesbian and gay people is unlikely to be achieved any time soon, certainly not so soon that we can be sure it will be the direct effect of any currently existing cause. There might be several more links in the chain between now and then, and the more links involved, the more opportunities there are for unforeseen causes to intervene and take history in some other direction. For this reason, any causation theory which culminates optimistically in equality is more likely a thinly veiled teleology theory. Teleology — the third possible motivation for statements of inevitability — is premised on a belief that history is progressing towards some ultimate end, in this case freedom or equality. The idea that history is being guided by a purpose in turn requires a more fundamental belief that history is rational in the sense that everything happens for a reason and nothing by chance. Perhaps these fatalists believe history behaves rationally in this way because they cannot contemplate the alternative: that the future is unknowable.

While each of these reasons provides some insight into underlying motives, none provides a solid basis for concluding that equality between the sexualities is in fact inevitable. Rhetorical statements are based on loose logic, causal reasoning tries to build a bridge too far and teleological reasoning is a baseless evolutionary trick our brains play on us. How then are gay law 
reform activists to face this reality that equality is not inevitable? With the comfort of a certain future ripped from under their feet, they may turn to despair, or they may become even more cynical and exploit the discourse of inevitability. Each of these options has its weaknesses. Being overwhelmed will not bring equality any closer and persisting with the language of inevitability may breed complacency. Worse still, clinging to inevitability rhetoric betrays 'a poverty of imagination', which leaves its adherents unprepared for regression. ${ }^{167}$ More practically, the strategy of continuing to invoke inevitability might not pay off if knowledge and power structures shift in an unfavourable direction. A more radical and transformative option open to equality activists is to move outside the framework of progress altogether. To do so they would need to cultivate active imaginations about the very best and very worst the future might bring so that they have goals in the wake of progress's demise, yet remain prepared. To assist in imagining alternative futures they may profit from engaging in a 'genealogical politics' that unsettles the settled present so as to lessen the weight of history on current realities and therefore future possibilities. Just one political possibility this may open up is a focus upon countertrends away from equality as a site of investigation and struggle for law reform. In sum, there is no positive basis for believing that formal equality for lesbian and gay people is inevitable, nor that it is irreversible. More likely, it is something we need to work hard for and to guard anxiously if we ever do attain it.

${ }^{167}$ Popper, above n 52, 130. 
